\title{
PENGHAPUSAN REMISI BAGI KORUPTOR DALAM PERSPEKTIF UNDANG-UNDANG NOMOR 12 TAHUN 1995 TENTANG PEMASYARAKATAN
}

\author{
Hilman Nur \\ Dosen Fakultas Hukum Universitas Suryakancana
}

\begin{abstract}
ABSTRAK
Korupsi di Indonesia sudah dikategorikan sebagai kejahatan yang luar biasa (extra ordinary crime) karena telah merusak, tidak saja keuangan negara dan potensi ekonomi negara, tetapi juga telah meluluhlantakkan pilar-pilar sosio budaya, moral, politik dan tatanan hukum dan keamanan nasional. Dengan adanya predikat luar biasa tersebut, maka muncul wacana untuk dilakukan penghapusan remisi bagi koruptor, sehingga hal ini yang kemudian menuai pro dan kontra di kalangan masyarakat. Adapun yang menjadi identifikasi masalah dalam penulisan artikel ini penulis batasi mengenai apakah penghapusan remisi bagi koruptor tersebut sudah sesuai dengan aturan hukum yang ada, atau justru malah bertentangan dengan hak asasi manusia. Metode yang digunakan dalam penelitian ini menggunakan pendekatan yuridis normatif, yaitu penelitian yang dilakukan dengan mendasarkan pada data kepustakaan atau data sekunder. Berdasarkan hasil penelitian ini, bahwa penghapusan remisi terhadap koruptor tidak sesuai dengan aturan perundang-undangan yang berlaku terutama Undang-Undang No. 12 Tahun 1995 Tentang Pemasyarakatan, khususnya Pasal 14 ayat (1) poin i, yang menyatakan bahwa "Narapidana berhak mendapatkan pengurangan masa pidana (remisi)". Oleh karena itu, apabila Pemerintah bermaksud memberikan efek jera yang lebih kuat terhadap pelaku tindak pidana korupsi, maka sebaiknya Pemerintah mensinergikan dahulu aturan perundang-undangan yang mengatur tentang pemberian remisi terhadap narapidana, sehingga tidak terjadi tumpang tindih kebijakan.
\end{abstract}

Kata Kunci : Korupsi, Remisi, Tujuan Pemidanaan.

\begin{abstract}
Corruption in Indonesia has been categorized as an extraordinary crime (extraordinary crime) for devastating, not only the country's financial and economic potential of the country, but also has destroyed the pillars of sociocultural, moral, political and legal order or national security. With the incredible title, then appeared the discourse for the removal of remission for corruption, so it is then reap the pro and contra among the people. As for the identification of the problem in writing this article the author limit as to whether the abolition of remissions for the corruptors is in conformity with the existing laws, or actually even contrary to human rights. The method used in this study using normative juridical approach, the research done by basing on literature data or secondary data. Based on these results, that the abolition of remission to criminals is not in
\end{abstract}


accordance with the rules of the applicable legislation, especially Regulation No. 12 Year 1995 on Corrections, particularly clause 14 subsection (1) points $i$, which states that "Prisoners are entitled to a reduction in criminal past (remission)". Therefore, if the Government intends to provide a more powerful deterrent effect against criminal act of corruption, then the Government should first rule synergize legislation governing the granting remission to prisoners, so there is no overlapping policies.

Keywords: Corruption, Remission, Objective Punishment.

\section{PENDAHULUAN.}

Dewasa ini bangsa Indonesia sedang dilanda penyakit yang sangat membahayakan bagi perjalanan bangsa ini ke depan, yaitu korupsi. Hampir di setiap tingkatan pekerjaan terjadi korupsi, baik itu dari tingkat bawah sampai pejabat tinggi. Ibarat penyakit, korupsi di Indonesia telah berkembang dalam tiga tahap, yaitu elitis, endemik, dan sistemik. Pada tahap elitis, korupsi masih menjadi patologi sosial yang khas di lingkungan para elit/pejabat. Pada tahap endemik, korupsi mewabah menjangkau lapisan masyarakat luas. Lalu ditahap yang kritis, ketika korupsi menjadi sistemik, setiap individu di dalam sistem terjangkit penyakit yang serupa. Oleh karena itu boleh jadi penyakit korupsi di bangsa ini telah sampai pada tahap sistemik. ${ }^{1}$

Indonesia sebagai negara yang penduduknya adalah mayoritas beragama Islam seharusnya lebih faham mengenai kandungan makna dalam Kitab Suci AlQur'an terutama dalam surat Al-Baqarah ayat 188 yang berbunyi "Dan janganlah sebagian kamu memakan harta sebagian yang lain diantara kamu dengan jalan yang bathil dan janganlah kamu membawa (urusan) harta itu kepada Hakim, supaya kamu dapat memakan sebagian daripada harta benda orang lain itu dengan (jalan berbuat) dosa, padahal kamu mengetahui".2 Ayat Al-Qur'an inilah yang seharusnya dijadikan dasar atau pedoman umat Islam khususnya dalam pencegahan tindak pidana korupsi. Korupsi telah dianggap sebagai hal yang biasa, dengan dalih "sudah sesuai prosedur". Koruptor tidak lagi memiliki rasa malu dan

1 Abu Fida' Abdur Rafi", Terapi Penyakit Korupsi dengan Tazkiyatun Nafs (Penyucian Jiwa), Republika, Jakarta, 2006, hIm. xi-xii.

2 Vide Al-Qur'an, Yayasan Penyelenggara Penterjemah/Pentafsir Al-Qur'an, Jakarta, 1971, hlm. 46. 
takut, sebaliknya memamerkan hasil korupsinya secara demonstratif. ${ }^{3}$

Pemerintah sendiri bukan tanpa upaya dalam menangani masalah korupsi ini, terbukti dengan banyaknya kebijakan-kebijakan yang diambil diantaranya tercatat sudah 4 (empat) kali membuat peraturan perundang-undangan tentang pemberantasan korupsi, mulai dari Undang-Undang No. 24 Prp Tahun 1960, Undang-Undang No. 3 Tahun 1971, Undang-Undang No. 31 Tahun 1999, dan terakhir Undang-Undang No. 20 Tahun 2001 sebagai perubahan atau penambahan terhadap beberapa ketentuan dalam Undang-Undang No. 31 Tahun 1999 yang dianggap belum lengkap. Namun harus diakui bahwa eksistensi lembaga pemerintah yang menangani perkara korupsi belum berfungsi secara efektif dan efisien dalam memberantas tindak pidana korupsi. Hal demikian diperparah oleh indikasi adanya keterlibatan aparat penegak hukum dalam penanganan kasus korupsi. Paling tidak terdapat tiga hal yang memperkuat argumen ini. Pertama, melalui media massa seringkali ditemukan adanya beberapa kasus korupsi besar yang tidak pernah jelas ujung akhir penanganannya. Kedua, pada kasus tertentu juga sering terjadi adanya kebijakan pengeluaran Surat Perintah Penghentian Penyidikan (SP3) oleh aparat terkait sekalipun bukti awal secara yuridis dalam kasus tersebut sesungguhnya cukup kuat. Ketiga, kalaupun suatu kasus korupsi penanganannya sudah sampai di persidangan Pengadilan, seringkali publik dikejutkan bahkan dikecewakan oleh adanya vonis-vonis yang melawan arus dan rasa keadilan masyarakat. ${ }^{4}$ Malah sekarang lebih memprihatinkan lagi, masyarakat sedang diberikan tontonan yang sangat memilukan dengan terjadinya konflik antara dua (2) lembaga penegakan hukum di negeri ini yaitu Komisi Pemberantasan Korupsi (KPK) dan Kepolisian Negara Republik Indonesia (POLRI). Terjadinya konflik antara dua lembaga penegakan hukum ini sangat menggangu kinerja keduanya terutama dalam upaya pemberantasan tindak pidana

3 Soetanto Soepiadhy, Gerakan Indonesia Patut, Mingguan Opini Kolom Suara Sejati, Edisi 10 Tahun I tanggal 18-16 September 2005,Jakarta, hIm. 2.

4 M. Abdul Kholiq, "Eksistensi dalam Peradilan Korupsi di Indonesia", Jurnal Hukum, No. 26 Vol 11 Mei 2004, hlm 31. Bandingkan dengan Ajarotni, Suradji, dan Theodrik Simorangkir (Editor), Penelitian Hukum tentang Aspek Hukum Pemberantasan Korupsi di Indonesia, Badan Pembinaan Hukum Nasional, Departemen Hukum dan Hak Asasi Manusia RI, Jakarta, 2008, hlm. 64-66. 
korupsi, yang akhirnya masyarakat menilai bahwa keadaan seperti ini justru malah menguntungkan para koruptor. Selanjutnya di tengah gencarnya semangat pemberantasan korupsi di negeri ini, kemudian muncullah wacana tentang penghapusan remisi atau pengurangan masa tahanan bagi koruptor, karena korupsi itu dianggap sebagai kejahatan yang luar biasa yang mengakibatkan kerugian yang besar bagi negara atau masyarakat atau korban yang banyak atau menimbulkan kepanikan, kecemasan, atau ketakutan yang luar biasa kepada masyarakat, dengan tujuan untuk memberikan penjeraan bagi para koruptor tersebut.

Wacana penghapusan remisi bagi koruptor ini mendapat respon beragam dari masyarakat. Salah satu pihak yang setuju dengan penghapusan remisi untuk koruptor tersebut adalah Indonesian Corruptiont Watch (ICW). Peneliti Indonesian Corruptiont Watch (ICW) Tama S Langkun menilai, penghapusan remisi bagi koruptor sejalan dengan semangat pemberantasan korupsi yang tercantum dalam Undang-Undang No. 20 Tahun 2001 Tentang Pemberantasan Korupsi Jo Undang-Undang No. 31 Tahun 1999 Tentang Pemberantasan Tindak Pidana Korupsi. Akan tetapi sebagian masyarakat yang lain ada juga yang tidak setuju. Beberapa pihak mengatakan bahwa kebijakan penghapusan remisi koruptor merupakan pelanggaran terhadap hak asasi manusia (HAM), karena sejatinya, remisi merupakan hak terpidana, sebagaimana pelaksanaannya diatur dalam Undang-Undang No. 12 Tahun 1995 Tentang Pemasyarakatan, khususnya Pasal 14 ayat (1). Berdasarkan latar belakang tersebut, maka permasalahan yang muncul yang coba penulis batasi adalah; Apakah penghapusan remisi bagi koruptor tersebut sudah sesuai dengan aturan hukum yang ada, atau justru malah bertentangan dengan hak asasi manusia ?

\section{PEMBAHASAN.}

Dari uraian di atas, dapat difahami bahwa begitu besarnya ancaman yang dihadapi bangsa ini ke depan yang diakibatkan oleh korupsi, sehingga perlu penanganan atau penegakan hukum yang benar-benar adil sesuai dengan aturan hukum yang berlaku di negara ini. Semua sepakat bahwa korupsi di bumi 
Indonesia ini harus dihapuskan, tetapi penanganan atau penegakan hukum terhadap koruptor juga harus sesuai dengan aturan hukum yang ada dan berlaku di negara ini, oleh karena itu, negara Indonesia sebagaimana yang dijelaskan dalam Konstitusi Undang-Undang Dasar (UUD) 1945 menyatakan bahwa negara Indonesia adalah negara yang berdasarkan atas hukum (rechtsstaat), tidak berdasarkan kekuasaan belaka (machtsstaat). Indonesia yang memutuskan Pancasila sebagai dasar negaranya menjadikan Pancasila sebagai sumber hukum materiil, yang mana sejalan dengan pendapat Aristoteles, yang menyatakan bahwa konsep negara hukum (rule of law) merupakan pemikiran yang dihadapkan (contrast) dengan konsep rule of man. ${ }^{5}$

Konsep negara hukum Indonesia yang berdasarkan Pancasila dan UndangUndang Dasar 1945 dapat dilihat secara material dan yuridis formal. Secara material negara hukum Pancasila didasarkan pada paradigma bangsa Indonesia dalam bernegara yang bersifat integralistik khas Indonesia, yaitu berasas kekeluargaan yang bermakna keutamaan bagi rakyat, penghargaan terhadap harkat dan martabat manusia dan keberlakuan hukum yang berfungsi memberikan pengayoman untuk tegaknya demokrasi, keadilan sosial dan peri kemanusiaan. ${ }^{6}$

Menurut Jimly Asshiddiqie, ide negara hukum, selain terkait dengan konsep rechtstaat dan the rule of law, juga berkaitan dengan konsep nomocracy yang berasal dari perkataan nomos dan cratos. Perkataan nomokrasi itu dapat dibandingkan dengan demos dan cratos atau kratein dalam istilah demokrasi. Nomos berarti norma, sedangkan cratos berarti kekuasaan. Maka yang menjadi faktor penentu dalam penyelenggaraan kekuasaan adalah norma atau hukum, sehingga istilah nomocracy tersebut berkaitan erat dengan pemikiran mengenai kedaulatan hukum atau prinsip hukum sebagai kekuasaan tertinggi. ${ }^{7}$ Dengan demikian, sejak kelahirannya, konsep negara hukum atau rule of law ini memang

5 Brian Z. Tamahana, On the Rule of Law, History, Politics, Theory, Cambridge University Press,2004, hlm. 9.

6 Padmo Wahyono, Pembangunan Hukum DI Indonesia, Ind-Hill Co, Jakarta, 1989, hlm. 153155.

7 Jimly Asshiddiqie, Cita Negara Hukum Indonesia, Pidato Orasi IImiah Pada Wisuda Sarjana Hukum Fakultas Hukum Sriwijaya Palembang Tanggal 23 Maret 2004, dimuat dalam Jurnal Hukum Simbur Cahaya No. 25 Tahun IX Mei 2005, hlm. 166. 
dimaksudkan sebagai usaha untuk membatasi kekuasaan penguasa negara agar tidak menyalahgunakan kekuasaan untuk menindas rakyatnya (abuse of power, abuse de droit). Atas dasar itu, dapat dikatakan bahwa dalam suatu negara hukum, semua orang harus tunduk kepada hukum secara sama, yakni tunduk kepada hukum yang adil. ${ }^{8}$

Negara hukum, ditempatkan sebagai aturan main dalam penyelenggaraan kenegaraan, pemerintahan, dan kemasyarakatan, sementara tujuan hukum itu sendiri antara lain " ...opgelegd om de samenleving vreedzaam, rechtvaardig, en doelmatig te ordenen", (diletakan untuk menata masyarakat yang damai, adil, dan bermakna). ${ }^{9}$ Artinya sasaran dari negara hukum adalah terciptanya kegiatan kenegaraan, pemerintahan, dan kemasyarakatan yang bertumpu pada keadilan, kedamaian, dan kemanfaatan atau kebermaknaan. Dalam negara hukum, eksistensi hukum dijadikan sebagai instrumen dalam menata kehidupan kenegaraan, pemerintahan, dan masyarakat. Berkenaan dengan hal tersebut, Negara Hukum (Rechtsstaat) Indonesia memiliki ciri-ciri khas Indonesia. Karena Pancasila harus diangkat sebagai norma dasar dan sumber hukum, maka Negara Hukum Indonesia dapat pula dinamakan 'Negara Hukum Pancasila'. Salah satu ciri pokok dalam Negara Hukum Pancasila ialah adanya jaminan terhadap 'freedom of religion' atau 'kebebasan beragama'. Tetapi kebebasan beragama di Negara Hukum Pancasila selalu dalam konotasi yang positif, artinya tiada tempat bagi ateisme atau propaganda anti agama di Bumi Indonesia ${ }^{10}$.

Selain ciri-ciri di atas Muhammd Tahir Azhari juga menyatakan ciri-ciri konsep Negara Hukum Pancasila meliputi : 1) adanya hubungan yang erat antara agama dan negara; 2) bertumpu pada Ketuhanan Yang Maha Esa; 3) kebebasan

8 Munir Fuady, Teori Negara Hukum Modern (Rechtstaat), Refika Aditama, Bandung, Cetakan Kedua, 2009, hlm. 2.

9 N.E. Algra dan H.C.J.G. Jansen, Rechtsingang Een Orientasi in Het Recht, H.D. Tjeenk Willink bv, Groningen, 1974, hlm. 10

10 Abdul Latif, Fungsi Mahkamah Konstitusi Dalam Upaya Mewujudkan Negara Hukum Demokrasi, Total Media, Yogyakarta, 2007, hlm. 96. 
beragama dalam arti positif; 4) ateisme tidak dibenarkan dan komunisme dilarang; 5) asas kekeluargaan dan kerukunan ${ }^{11}$.

Tujuan utama bentuk negara hukum adalah untuk menyelenggarakan ketertiban hukum, yakni tata tertib yang umumnya berdasarkan hukum yang terdapat pada rakyat. Negara hukum menjaga ketertiban hukum supaya jangan terganggu dan agar semuanya berjalan menurut hukum. Seperti yang diutarakan oleh A. Mukhtie Fadjar ${ }^{12}$, bahwa negara hukum ialah negara yang susunannya diatur dengan sebaik-baiknya dalam undang-undang sehingga segala kekuasaan dari alat-alat pemerintahannya didasarkan pada hukum. Rakyat tidak boleh bertindak secara sendiri-sendiri menurut kemampuannya yang bertentangan dengan hukum. Negara hukum itu ialah negara yang diperintah bukan oleh orangorang tetapi oleh undang-undang (the states not governed by men, but by law).

Agar negara dapat dikategorikan sebagai negara hukum, maka negara tersebut haruslah memenuhi beberapa persyaratan sebagai berikut : 1) Perlindungan hak-hak rakyat oleh pemerintah; 2) Kekuasaan lembaga negara tidak absolut; 3) Berlakunya prinsip trias politica; 4) Pemberlakuan sistem 'checks and balances'; 5) Mekanisme pelaksanaan kelembagaan negara demokratis; 6) Kekuasaan lembaga kehakiman yang bebas dan mandiri; 7) Sistem pemerintahan yang transparan; 8) Adanya kebebasan pers; 9) Adanya keadilan dan kepastian hukum; 10) Akuntabilitas publik dari pemerintah dan pelaksanaan prinsip ' good governance'; 11) Sistem hukum yang tertib berdasarkan konstitusi; 12) Keikutsertaan rakyat untuk memilih para pemimpin di bidang eksekutif, legislatif, bahkan juga yudikatif sampai batas-batas tertentu; 13) Adanya sistem yang jelas terhadap pengujian suatu produk legislatif, eksekutif maupun yudikatif untuk disesuaikan dengan konstitusi. Pengujian tersebut dilakukan oleh pengadilan tanpa menyebabkan pengadilan atau legislatif menjadi 'super body'; 14) Dalam negara hukum, segala kekuasaan negara harus dijalankan sesuai dengan konstitusi dan hukum yang berlaku; 15) Negara hukum harus memberlakukan prinsip 'due

11 Muhammad Tahir Azhari, Negara Hukum Studi Tentang Prinsip-prinsipnya dilihat dari Segi Hukum Islam, Implementasinya pada Periode Negara Madinah dan Masa Kini, Cet. II, Prenada Media, Jakarta, 2003, hlm. 99.

12 A. Mukhtie Fadjar, Tipe Negara Hukum, Bayumedia Publishing, Malang, 2005, hlm. 7. 
process' yang substansial; 16) Prosedur penangkapan, penggeledahan, pemeriksaan, penyidikan, penuntutan, penahanan, penghukuman, dan pembatasan-pembatasan hak-hak si tersangka pelaku kejahatan haruslah dilakukan secara sesuai dengan prinsip 'due proses' yang prosedural; 17) Perlakuan yang sama diantara warga negara di depan hukum; 18) Pemberlakuan prinsip 'majority rule minority protection'; 19) Proses 'impeachment' yang fair dan objektif; 20) Prosedur pengadilan yang fair, efisien, reasonable, dan transparan; 21) Mekanisme yang fair, efisien, reasonable, dan transparan tentang pengujian terhadap tindakan aparat pemerintah yang melanggar hak-hak warga masyarakat, seperti melalui Pengadilan Tata Usaha Negara; 22) Penafsiran yang kontemporer terhadap konsep negara hukum mencakup juga persyaratan penafsiran hak rakyat yang luas (termasuk hak untuk memperoleh pendidikan dan tingkat hidup berkesejahteraan), pertumbuhan ekonomi yang bagus, pemerataan pendapatan, dan sistem politik dan pemerintahan yang modern.

Negara Hukum Indonesia berdasarkan Pancasila dan Undang-Undang Dasar Negara Republik Indonesia Tahun 1945 pada hakikatnya berkewajiban untuk memberikan perlindungan dan pengakuan terhadap penentuan status pribadi dan status hukum setiap Peristiwa Kependudukan dan Peristiwa Penting yang dialami oleh Penduduk yang berada di dalam dan/atau di luar wilayah Negara Kesatuan Republik Indonesia. Hamid S. Attamimi, dengan mengutip Burkens, mengatakan bahwa negara hukum (rechtstaat) secara sederhana adalah negara yang menempatkan hukum sebagai dasar kekuasaan negara dan penyelenggaraan kekuasaan tersebut dalam segala bentuknya dilakukan di bawah kekuasaan hukum ${ }^{13}$. Dalam negara hukum, segala sesuatu harus dilakukan menurut hukum (everything must be done according to law). Negara hukum menentukan bahwa pemerintah harus tunduk pada hukum, bukannya hukum yang harus tunduk pada pemerintah. ${ }^{14}$ Pendapat tersebut sejalan dengan konsep negara hukum P.J.P. Tak. $^{15}$

13 A. Hamid S. Attamimi, Teori Perundang-Undangan Indonesia, Makalah pada Pidato Upacara Pengukuhan Jabatan Guru Besar Tetap di Fakultas Hukum UI Jakarta, 25 April 1992, hlm. 8.

14 H.W.R. Wade, Administrative Law, Third Edition (Oxford: Clarendon Press, 1971), hlm. 6.

15 P.J.P. Tak, Rechtsvorming in Nederland, Samsom H.D. Tjeenk Willink, 1991, hlm. 32. 
Pembukaan Undang-Undang Dasar Negara Republik Indonesia Tahun 1945 yang terekam dalam sejarah perjalanan bangsa Indonesia khususnya berkenaan dengan Indonesia sebagai negara hukum berfungsi sebagai memori kolektif bangsa. Konsep negara hukum tersebut tercermin secara implisit yang harus dipahami oleh seluruh komponen masyarakat, bangsa, dan negara baik itu lembaga negara, pemerintahan daerah, lembaga pendidikan, organisasi kemasyarakatan, organisasi politik, perusahaan, maupun perseorangan. Memori kolektif bangsa yang merupakan sebagian rekaman dari sejarah perjalanan bangsa tersebut merupakan aset nasional yang menggambarkan identitas dan jati diri bangsa Indonesia yang sesungguhnya. Setiap langkah dan dinamika gerak maju bangsa sebagai negara hukum, masyarakat, dan negara Indonesia ke depan harus didasarkan pada pemahaman, penghayatan, dan catatan atas identitas dan jati diri bangsa tersebut yang terekam dalam bentuk budaya. Berkaitan dengan masalah remisi, bahwa hal tersebut sudah ada aturan, dasar hukum, undangundang yang mengaturnya yaitu melalui Undang-Undang No. 12 Tahun 1995 Tentang Pemasyarakatan, khususnya Pasal 14 ayat (1) poin i, yang menyatakan bahwa "Narapidana berhak mendapatkan pengurangan masa pidana (remisi)".

Selanjutnya Pasal 34A ayat (1) Peraturan Pemerintah Republik Indonesia N. 99 Tahun 2012 Tentang Perubahan Kedua Atas Peraturan Pemerintah No. 32 Tahun 1999 Tentang Syarat Dan Tata Cara Pelaksanaan Hak Warga Binaan Pemasyarakatan menyatakan "Pemberian Remisi bagi Narapidana yang dipidana karena melakukan tindak pidana terorisme, narkotika dan prekursor narkotika, psikotropika, korupsi, kejahatan terhadap keamanan negara, kejahatan hak asasi manusia yang berat, serta kejahatan transnasional terorganisasi lainnya, selain harus memenuhi persyaratan sebagaimana dimaksud dalam Pasal 34 juga harus memenuhi persyaratan: a). bersedia bekerjasama dengan penegak hukum untuk membantu membongkar perkara tindak pidana yang dilakukannya; b). telah membayar lunas denda dan uang pengganti sesuai dengan putusan pengadilan untuk Narapidana yang dipidana karena melakukan tindak pidana korupsi.

Mengenai pengertian remisi ini, dalam Pasal 14 Undang-Undang No. 12 Tahun 1995 Tentang Pemasyarakatan menyebutkan bahwa remisi adalah 
pengurangan masa pidana yang diberikan kepada narapidana yang memenuhi syarat. Menurut Andi Hamzah, remisi adalah sebagai pembebasan hukuman untuk seluruhnya atau sebagian atau dari seumur hidup menjadi hukuman terbatas yang diberikan setiap tanggal 17 Agustus. ${ }^{16}$ Berdasarkan Peraturan Pemerintah Republik Indonesia No. 32 Tahun 1999 Tentang Syarat dan Tata Cara Pelaksanaan Hak Warga Binaan Pemasyarakatan, remisi adalah pengurangan masa menjalani pidana yang diberikan kepada narapidana dan Anak Pidana yang memenuhi syarat-syarat yang ditentukan dalam peraturan perundang-undangan (lihat Pasal 1 angka 6). Sedangkan menurut ketentuan Pasal 1 Keputusan Presiden Republik Indonesia No. 174 Tahun 1999 Tentang Remisi, tidak memberikan pengertian remisi hanya dikatakan bahwa : "Setiap narapidana dan anak pidana yang menjalani pidana penjara sementara dan pidana kurungan dapat diberikan remisi apabila yang bersangkutan berkelakuan baik selama menjalani pidana". ${ }^{17}$

Pasal 1 ayat (1) Keputusan Menteri Hukum dan Perundang-undangan Republik Indonesia Nomor: M.09.HN.02.01 tahun 1999, menyebutkan bahwa remisi adalah pengurangan masa pidana yang diberikan kepada narapidana dan anak pidana yang telah berkelakuan baik selama menjalani pidana. Memberi remisi sebagaimana dimaksud dalam Keputusan Presiden Republik Indonesia No. 174 Tahun 1999 Tentang Remisi tidak ditafsirkan sebagai kemudahan dalam kebijakan menjalani pidana, sehingga mengurangi arti pemidanaan namun memberikan remisi tersebut adalah dalam upaya mengurangi dampak negatif dari subkultur tempat pelaksanaan pidana, disparitas pidana dan akibat pidana perampasan kemerdekaan. Secara psikologis pemberian remisi mempunyai pengaruh menekan tingkat frustasi, sehingga dapat mereduksi atau meminimalisasi ganggungan keamanan dan ketertiban di Lembaga Pemasyarakatan, Rumah Tahanan dan Cabang Rumah Tahanan Negara, berupa pelarian, perkelahian dan kerusuhan lainnya. Pada sistem baru pembinaan narapidana, remisi ditempatkan sebagai motivasi (salah satu motivasi) bagi narapidana untuk membina diri sendiri. Sebab, remisi tidak sebagai hukum

16 Andi Hamzah, Kamus Hukum, dalam Dwidja Priyatno, Sistem Pelaksanaan Pidana Penjara Di Indonesia, Cet. 2, PT. Refika Aditama, Bandung, 2009, hlm. 133.

17 Dwidja Priyatno, Sistem Pelaksanaan Pidana.......... Op Cit, hlm. 133-134. 
seperti dalam Sistem Pemasyarakatan, tidak pula sebagai anugerah sebagaimana dalam sistem kepenjaraan, tetapi sebagai hak dan kewajiban narapidana. Artinya jika narapidana benar-benar melaksanakan kewajibannya, ia berhak untuk mendapat remisi, sepanjang persyaratannya telah dipenuhi. ${ }^{18}$

Kriteria pemberian remisi perlu diperjelas, sehingga dapat menutup peluang remisi menjadi komoditas. Meski remisi adalah hak narapidana, tetap perlu ada kondisi khusus yang ikut menentukan diberi atau tidaknya pengurangan hukuman dan lamanya pengurangan hukuman bagi narapidana. Menurut Indriyanto Seno Adji, pemberian remisi yang dimonopoli Lembaga Pemasyarakatan perlu mendapat kontrol dari luar. Ia menyarankan perlunya fungsi pengawasan dalam pemberian remisi. Sebagai lembaga pembinaan, posisinya sangat strategis dalam merealisasikan tujuan akhir dari sistem peradilan, yaitu rehabilitasi dan resosialisasi pelanggar hukum, bahkan sampai kepada penangguhan kejahatan (Suppression of Crime). Keberhasilan dan kegagalan pembinaan yang dilakukan Lembaga Pemasyarakatan akan memberikan kemungkinan penilaian yang dapat bersifat positif maupun negatif. ${ }^{19}$

Adapun mengenai dasar hukum pemberian remisi sudah mengalami beberapa kali perubahan, bahkan untuk tahun 1999 telah dikeluarkan Keputusan Presiden (Keppres) No. 69 Tahun 1999 dan belum sempat diterapkan akan tetapi kemudian dicabut kembali dengan Keppres No. 174 Tahun 1999. Remisi yang berlaku dan pernah berlaku di Indonesia sejak jaman Belanda sampai sekarang adalah berturut-turut sebagai berikut : 1) Gouvernement Besluit tanggal 10 Agustus 1935 No. 23 Bijblad No. 13515 Jo. 9 Juli 1841 No. 12 dan 26 Januari 1942 No. 22; Merupakan yang diberikan sebagai hadiah semata-mata pada hari kelahiran Sri Ratu Belanda, 2) Keputusan Presiden Nomor 156 tanggal 19 April 1950 yang termuat dalam Berita Negara No. 26 Tanggal 28 April 1950 Jo. Peraturan Presiden RI No. 1 Tahun 1946 tanggal 8 Agustus 1946 dan Peraturan Menteri Kehakiman RI No.G.8/106 tanggal 10 Januari 1947 Jo. Keputusan Presiden RI Nomor 120 Tahun1955, tanggal 23 Juli 1955 Tentang Ampunan

18 Cl. Harsono, Sistem Baru Pembinaan Narapidana, Djambatan, Jakarta, 1995, hlm. 25.

19 Petrus Irwan Panjaitan Dan Pandapotan Simorangkir, Lembaga Pemasyarakatan Dalam Perspektif Sistem Peradilan Pidana, Pustaka Sinar Harapan, Jakarta, 1995, hlm. 65. 
Istimewa. 3) Keputusan Presiden No. 5 Tahun 1987 Jo. Keputusan Menteri Kehakiman RI No. 01.HN.02.01 Tahun 1987 Tentang Pelaksanaan Keputusan Presiden No. 5 Tahun 1987, Keputusan Menteri Kehakiman RI No. 04.HN.02.01 Tahun 1988 tanggal 14 Mei 1988 Tentang Tambahan Remisi Bagi Narapidana yang Menjadi Donor Organ Tubuh dan Donor Darah dan Keputusan Menteri Kehakiman RI No. 03.HN.02.01 tahun 1988 tanggal 10 Maret 1988 Tentang Tata Cara Permohonan Perubahan Pidana Penjara Seumur Hidup menjadi pidana penjara sementara berdasarkan Keputusan Presiden RI No. 5 Tahun 1987. 4) Keputusan Presiden No. 69 Tahun 1999 Tentang Pengurangan Masa Pidana (Remisi). 5) Keputusan Presiden No. 174 Tahun 1999 Jo. Keputusan Menteri Hukum dan Perundang-undangan RI No. M.09.HN.02.01 Tahun 1999 Tentang Pelaksanaan Keputusan Presiden No. 174 Tahun 1999, Keputusan Menteri Hukum dan Perundang-undangan No. M.10.HN.02.01 Tahun 1999 Tentang Pelimpahan Wewenang Pemberian Remisi Khusus. ${ }^{20}$

Ketentuan yang masih berlaku adalah ketentuan yang terbaru, yaitu Nomor lima (5), tetapi ketentuan tersebut masih ditambahkan dengan beberapa ketentuan yang lain, sehingga ketentuan yang masih berlaku untuk remisi saat ini adalah : 1) Keputusan Presiden RI No. 120 Tahun 1955, tanggal 23 Juli 1955 Tentang Ampunan Istimewa; 2) Keputusan Menteri Kehakiman RI No. 04.HN.02.01 Tahun 1988 tanggal 14 Mei 1988 Tentang Tambahan Remisi Bagi Narapidana yang Menjadi Donor Organ Tubuh dan Donor Darah; 3) Keputusan Menteri Hukum dan Perundang-undangan RI No. M.09.HN.02.01 Tahun 1999 Tentang Pelaksanaan Keputusan Presiden No. 174 Tahun 1999; 4) Keputusan Menteri Hukum dan Perundang-undangan No. M.10.HN.02.01 Tahun 1999 Tentang Pelimpahan Wewenang Pemberian Remisi Khusus; 5) Surat Edaran No. E.PS.0103-15 Tanggal 26 Mei 2000 Tentang Perubahan Pidana Penjara Seumur Hidup Menjadi Pidana Penjara; dan 6) Surat Edaran No. W8-PK.04.01-2586, tanggal 14 April 1993 Tentang Pengangkatan Pemuka Kerja. ${ }^{21}$

20 Dwidja Priyatno, Sistem Pelaksanaan Pidana.......... Ibid, hlm. 134-135.
21 Dwidja Priyatno, Sistem Pelaksanaan Pidana.......... bid, hlm. 135. 
Selanjutnya seperti disebutkan diatas, ada pula Peraturan Pemerintah No. 99 Tahun 2012 Tentang Perubahan Kedua Atas Peraturan Pemerintah No. 32 Tahun 1999 Tentang Syarat Dan Tata Cara Pelaksanaan Hak Warga Binaan Pemasyarakatan, merupakan Peraturan Pemerintah yang terbaru mengenai pemberian remisi. Apabila dilihat dari pandangan Hak Asasi Manusia (HAM), manusia menurut kodratnya memiliki hak yang melekat tanpa pengecualian, seperti hak untuk hidup, hak atas keamanan, hak bebas dari segala macam penindasan dan lain-lain yang secara universal disebut Hak Asasi Manusia (HAM). HAM harus dijamin oleh negara terhadap setiap individu, baik warga negaranya maupun warga negara asing, tanpa membedakan ras, bangsa, agama ataupun golongan tertentu. Setiap individu harus dijamin haknya, karena itu HAM tidak dapat dicabut oleh siapapun termasuk oleh dirinya sendiri. Istilah HAM berarti hak tersebut ditentukan dalam hakikat kemanusiaan dan demi kemanusiaan. $^{22}$ HAM yang merupakan hak dasar seluruh umat manusia sebagai anugerah Tuhan yang melekat pada diri manusia, bersifat kodrati, universal, abadi yang berhubungan dengan harkat dan martabat manusia, dimiliki sama oleh setiap orang, tanpa memandang jenis kelamin, kewarganegaraan, agama, usia, bahasa, status sosial, pandangan politik dan lain-lain. ${ }^{23}$

Indonesia sebagai salah satu negara yang berdasarkan rule of law sangat menjunjung tinggi HAM, yang diwujudkan dengan mengaturnya dalam berbagai peraturan, diantaranya dalam Undang-Undang Dasar 1945 sebagai hukum dasar (groundnorm), yang kemudian dipertegas dalam Undang-Undang No. 39 Tahun 1999 Tentang Hak Asasi Manusia. Sebagai konsekuensi pengakuan terhadap Hak Asasi Manusia, Indonesia sendiri mengakui bahwa semua manusia yang hidup di bumi Indonesia ini berhak mendapatkan perlindungan hak-hak asasinya, tanpa terkecuali para narapidana yang sedang menjalani masa hukuman di Lembaga Pemasyarakatan harus diberikan dan dilindungi hak-hak asasinya. Berkaitan

22 Anton baker, dalam St. Harum Pudjiarto, RS, Hak Asasi Manusia Kajian Filosofis dan Implementasinya Dalam Hukum Pidana di Indonesia, Universitas Atmajaya, Yogyakarta, 1999, hlm. 2.

23 Liona Nanang Supriatna, The Implementation of Internasional Hukum Rights Law in The Internasional Legal System, Johannes Herrmann Verlag, Gieben, 2008, hlm. 78. 
dengan upaya pembinaan narapidana di Lembaga Pemasyarakatan, hal ini tidak terlepas dari adanya dasar atau alasan pembenaran pidana penjara sebagai salah satu sarana politik kriminal. Dasar pembenaran digunakannya sanksi pidana, termasuk pidana penjara, merupakan salah satu masalah sentral dalam politik kriminal. $^{24}$

Bertolak dari konsepsi politik kriminal yang rasional seperti dikemukakan di atas, maka jelaslah bahwa tanpa terlebih dahulu menetapkan tujuan yang ingin dicapai, tidak dapat menyatakan pidana penjara itu merupakan sarana yang rasional atau tidak. Dengan demikian tidak dapat dikatakan pidana penjara itu merupakan sarana efektif dan bermanfaat atau tidak. Selanjutnya berarti, tidak dapat memberikan dasar pembenaran pada setiap jenis pidana yang dipilih, termasuk pidana penjara. Oleh karena itu, sebelum membahas masalah ini lebih lanjut perlu terlebih dahulu dibicarakan mengenai "tujuan yang ingin dicapai" itu. $^{25}$

Terhadap tujuan pidana terlebih dahulu dapat dikemukakan beberapa pandangan dari para ahli terdahulu yaitu :

1. Spinoza dan J.J. Roessau berpendapat :

"Tujuan pidana untuk memulihkan keadaan yang harmonis sebagai akibat dari gangguan perbuatan narapidana dan cara memulihkan keadaan yang demikian itu adalah dengan menakut-nakuti disamping harus diusahakan perbaikannya".

2. Muladi dan Barda Nawawi Arief dalam bukunya yang berjudul Pidana dan Pemidanaan berkesimpulan, Pidana mengandung unsur-unsur atau ciri-ciri sebagai berikut : a) Pidana itu pada hakekatnya merupakan suatu pengenaan penderitaan atau nestapa atau akibat-akibat lain yang tidak menyenangkan, b) Pidana itu diberikan dengan sengaja oleh orang atau badan yang mempunyai kekuasaan (oleh yang berwenang), dan c) Pidana

24 Karl O. Christiansen, Some Consideration on the Possibility of a Rational Criminal Policy. UNAFEI No. 7, 1974, hlm. 73-74.

25 Barda Nawawi Arief, Kebijakan Legislatif Dalam Penanggulangan Kejahatan dengan Pidana Penjara, Cetakan Keempat, Genta Publishing, Yogyakarta, 2010, hlm. 82. 
itu dikenakan kepada seseorang yang telah melakukan tindak pidana menurut undang-undang", ${ }^{26}$

Selanjutnya jika disimak mengenai tujuan pemidanaan dalam kepustakaan hukum pidana dapat dibagi-bagi kedalam tiga kelompok yaitu :

\section{Teori Absolut Atau Teori Pembalasan.}

Teori ini disebut retributif atau verdegeldings theory, menurut teori ini pidana dijatuhkan semata-mata karena orang-orang telah melakukan kejahatan atau tindak pidana. Pidana merupakan akibat mutlak yang harus ada sebagai suatu pembalasan kepada orang yang melakukan kejahatan dan tujuan utama dari pidana menurut teori ini adalah untuk memuaskan tuntutan keadaan. Dasar pembenaran teori absolut adalah terletak pada adanya atau terjadinya kejahatan itu sendiri.

Menurut Van Bemmelen, : "teori pembalasan terjadi atas pembalasan subjektif dan pembalasan objektif. Pembalasan subjektif ialah pembalasan terhadap kesalahan pelaku, sedang pembalasan objektif adalah pembalasan terhadap apa yang telah diciptakan pelaku terhadap dunia lain', ${ }^{27}$ Adapun ciriciri pokok dari teori absolut ini adalah : a) Tujuan pidana adalah semata-mata pembalasan, b) Pembalasan adalah tujuan utama dan di dalamnya tidak mengandung saran-saran untuk tujuan lain misalnya kesejahteraan masyarakat, c) Kesalahan adalah salah satunya syarat untuk adanya pidana, d) Pidana harus disesuaikan dengan kesalahan si pelanggar, dan e) Pidana melihat ke belakang, ia merupakan pencelaan yang murni dan tujuannya tidak untuk memperbaiki, mendidik atau memasyarakatkan kembali pelanggar.

\section{Teori Relatif Atau Teori Tujuan.}

Teori ini disebut juga dengan teori utilitarian atau teologis, menurut teori ini memidana bukanlah untuk memuaskan tuntutan absolut dari keadilan, sehingga pembalasan dianggap tidak mempunyai nilai, tetapi hanya sebagai sarana untuk melindungi masyarakat. Selain itu, pidana dijatuhkan bukanlah

26 Barda Nawawi Arief dan Muladi, Pidana dan Pemidanaan, F.H, Unsoed, Purwokerto, 1983, hlm. 3.

27 Bambang Poernomo, Perspektif Hukum Pelaksanaan Pidana Berdasarkan Pengayoman, Makalah Seminar, Pascasarjana UGM, Yogyakarta, 22 September 1990, hlm. 31. 
untuk pembalasan pada orang yang telah melakukan kejahatan, tetapi mempunyai tujuan tertentu yang bermanfaat. Tujuan- tujuan tertentu yang bermanfaat disini mempunyai maksud menjadikan orang-orang yang bersalah untuk menjadi orangorang yang lebih baik, juga berkaitan dengan dunia, misalnya dengan mengisolasi dan memperbaiki penjahat atau pencegah potensial, sehingga karenanya dunia akan menjadi tempat yang lebih baik. Adapun ciri yang terdapat pada teori relatif ini adalah: a) Tujuan pidana adalah pencegahan (prevention); b) Pencegahan bukan tujuan akhir tetapi hanya sebagai sarana untuk mencapai tujuan yang lebih tinggi yaitu kesejahteraan masyarakat; c) Hanya pelanggaran-pelanggaran hukum yang dapat dipersalahkan karena si pelaku saja (misalnya karena sengaja atau culpa) yang memenuhi syarat adanya pidana; d) Pidana harus ditetapkan berdasarkan tujuannya sebagai alat untuk mencegah kejahatan; dan e) Pidana (bersifat prospektif) pidana dapat mengandung unsur pencelaan, tetapi unsur pencelaan maupun unsur pembalasan tidak dapat diterima apabila tidak membantu pencegahan kejahatan untuk kepentingan kesejahteraan masyarakat. Adapun dasar pembenaran teori relatif adalah terletak pada tujuannya, sehingga pidana dijatuhkan bukan karena orang yang berbuat kejahatan, melainkan agar orang jangan melakukan kejahatan atau nepeccatur.

\section{Teori Gabungan.}

Timbulnya teori ini adalah sebagai akibat adanya ketidakpuasan terhadap kedua teori terdahulu yang dianggap kurang mampu dalam menanggulangi kejahatan. Oleh karena itu, timbul usaha untuk menghubungkan secara terpadu antara pandangan utilitas yang menyatakan tujuan pidana harus dapat menimbulkan manfaat yang dapat dibuktikan, dengan pandangan yang retributif yang menyatakan bahwa keadilan dapat tercapai apabila tujuan yang teological tersebut dilakukan dengan menggunakan ukuran-ukuran berdasarkan pirinsipprinsip keadilan. Jadi, singkatnya teori ini menghubungkan dan menggabungkan prinsip-prinsip retribution dengan utilaterian misalnya mencegah sekaligus rehabilitasi yang semuanya dapat dilihat sebagai sasaran yang harus dicapai oleh 
suatu rencana pemidanaan. Oleh karena itu teori gabungan sering disebut sebagai teori integratif. ${ }^{28}$

Teori ini menyatakan bahwa tujuan penjatuhan pidana selain untuk pembalasan kepada pelaku atas kejahatannya, juga bermaksud untuk mengamankan masyarakat. Kedua tujuan tersebut, bertujuan untuk mengantisipasi dan mengembalikan terpidana ke dalam masyarakat. ${ }^{29}$ Adapun ciri-cirinya sebagai berikut : a) Tujuan pemidanaan terhadap pencegahan umum dan khusus; b) Adanya perlindungan terhadap masyarakat; c) Memelihara solidaritas masyarakat; dan d) Terdapatnya pengimbalan dan pengimbangan.

Selanjutnya dalam hukum itu dikenal suatu asas, yaitu asas legalitas yang tercermin dari ungkapan dalam bahasa Latin : Nullum Delictum Nulla Poena Sine Praevia Lege poenali (tiada delik tiada hukuman sebelum ada ketentuan terlebih dahulu). Asas ini merupakan suatu jaminan dasar bagi kebebasan individu dengan memberi batas aktivitas apa yang dilarang secara tepat dan jelas. Asas ini melindungi dari penyalahgunaan kekuasaan atau kesewenang-wenangan Hakim, menjamin keamanan individu dengan informasi yang boleh dan yang dilarang. Setiap orang harus diberi peringatan sebelumnya tentang perbuatan-perbuatan ilegal dan hukumnya. ${ }^{30}$

Menurut Muladi, pidana penjara seperti yang di atur dalam pasal-pasal KUHP, sepertinya sudah bukan merupakan alternatif perbaikan pidana penjara ke arah yang lebih manusiawi dan menghindari dampak negatif bagi perkembangan sosial kemasyarakatan Terpidana. ${ }^{31}$ Artinya bahwa apabila Narapidana selama di Lembaga Pemasyarakatan selalu diperlakukan hukuman, baik hukuman fisik maupun hukuman batiniah, maka setelah keluar dari "tembok penjara", ada kemungkinan akan dapat menjadi penjahat yang kelasnya menjadi lebih hebat atau kejam, dikarenakan membawa dendam dan akan dapat menjadi momok yang mengerikan bagi masyarakat, sehingga dalam hal ini masyarakat tentu akan menjadi trauma dalam

28 Muladi, Lembaga Pidana Bersyarat, Alumni, Bandung, 1992, hlm. 51-53.

29 Andi Hamzah dan Siti Rahayu, Suatu Tinjauan Ringkas Sistem Pemidanaan Di Indonesia, Akademiko Pesindo, Jakarta, 1983, hlm. 36.

30 Topo Santoso, Membumikan Hukum Pidana Islam Penegakan Syariat Dalam Wacana Dan Agenda, Gema Insani, Jakarta, 2003, hlm. 10-11.

31 Muladi, Lembaga Pidana Bersyarat, Alumni, Bandung, 1992, hlm. 30. 
menerima bekas Narapidana dalam kehidupan mereka sehari-hari. Dengan pembinaan yang sebaik-baiknya di Lembaga Pemasyarakatan, akan memberikan manfaat besar bagi masyarakat dan negara, sehingga tidak lagi terganggu kepentingannya, dan seterusnya dapat merasakan ketentraman hidup, tidak selalu hidup dalam kecemasan yang akan selalu terganggu karena adanya kejahatan yang muncul di tengah-tengah kehidupan mereka. Oleh karena itu, pemberian remisi diharapkan akan benar-benar memberikan pengaruh baik dan manfaat, khususnya bagi Narapidana itu sendiri, bagi bekas Narapidana, serta bagi masyarakat luas dan negara pada umumnya. ${ }^{32}$

Dari sudut pandang agama pun kaum ulama mengatakan bahwa Tuhan-pun memaafkan orang yang berdosa yang betul-betul taubat, maka manusia hendaknya juga mau memberi maaf kepada orang yang bersalah, lebih-lebih kepada mereka yang betul-betul ingin kembali menjadi warga masyarakat yang baik. Sebagai dasar diantaranya adalah :

1. Kitab Suci Al-Qur'an Surat Al-Bara'ah (At-Taubah) ayat 102, yang artinya : "Dan (ada pula) orang-orang lain yang mengakui dosa-dosa mereka, mereka mencampurbaurkan pekerjaan yang baik dengan pekerjaan lain yang buruk. Mudah-mudahan Allah menerima taubat mereka. Sesungguhnya Allah Maha Pengampun dan Penyayang".

2. Kitab Suci Al-Qur'an Surat An-Nahl Ayat 119 yang artinya :

"Kemudian, sesungguhnya Tuhanmu (mengampuni) bagi orang-orang yang mengerjakan kesalahan karena kebodohannya, kemudian mereka bertaubat sesudah itu dan memperbaiki (dirinya); sesungguhnya Tuhanmu sesudah itu benar-benar Maha Pengampun lagi Maha Penyayang".

3. Kitab Suci Al-Qur'an Surat Al-Isra ayat 25, yang artinya :

"Tuhanmu lebih mengetahui apa yang ada dalam hatimu; jika kamu orangorang yang baik, maka sesungguhnya Dia Maha Pengampun bagi orangorang yang bertaubat", 33

Oleh karena itu kebijakan penghapusan remisi bagi Narapidana korupsi menurut hemat Penulis bertentangan dengan hukum positif yang berlaku di Indonesia, yaitu Undang-Undang Nomor 12 Tahun 1995 Tentang Pemasyarakatan. Ini berarti bahwa remisi adalah hak Narapidana itu sendiri sepanjang Narapidana tersebut berkelakuan baik dan memenuhi syarat-syarat yang di atur dalam undang-undang.

32 Sigit Setyadi, Kebijakan Pemberian Remisi Kepada Narapidana Di Yogyakarta, Tesis, Program Magister Ilmu Hukum, Universitas Diponegoro, Semarang, 2005, hlm. 65.

33 Al-Qur'an dan Terjemahnya, Yayasan Penyelenggara Penterjemah/Pentafsir Al-Qur'an, Jakarta, 1971. 


\section{PENUTUP.}

\section{A. Kesimpulan.}

Berdasarkan Undang-Undang No. 12 Tahun 1995 Tentang Pemasyarakatan, khususnya Pasal 14 ayat (1) poin i, menyatakan bahwa "Narapidana berhak mendapatkan pengurangan masa pidana (remisi)".

Indonesia sebagai salah satu negara yang berdasarkan rule of law sangat menjunjung tinggi HAM, yang diwujudkan dengan mengaturnya dalam berbagai peraturan, diantaranya dalam Undang-Undang Dasar 1945 sebagai hukum dasar (groundnorm), yang kemudian dipertegas dalam Undang-Undang Nomor 39 Tahun 1999 Tentang Hak Asasi Manusia, maka sebagai konsekuensi pengakuan terhadap Hak Asasi Manusia, Indonesia sendiri mengakui bahwa semua manusia yang hidup di bumi Indonesia ini berhak mendapatkan perlindungan hak-hak asasinya, tanpa terkecuali para narapidana yang sedang menjalani masa hukuman di Lembaga Pemasyarakatan harus diberikan dan dilindungi hak-hak asasinya.

Dari sudut pandang agama, kaum ulama mengatakan bahwa Tuhan-pun memaafkan orang yang berdosa yang betul-betul taubat, maka manusia hendaknya juga mau memberi maaf kepada orang yang bersalah, lebih-lebih kepada mereka yang betul-betul ingin kembali menjadi warga masyarakat yang baik.

\section{B. Saran.}

Pendapat penulis mengenai hal ini bukan berarti penulis sendiri pro koruptor, tetapi berusaha mendudukannya pada aturan hukum yang ada yang berlaku di negara ini. Oleh karena itu saran penulis sebaiknya agar tidak terjadi polemik mengenai hal ini, maka perlu ada perubahan atau revisi terhadap aturan hukum atau Undang-Undang terutama Undang-Undang No. 12 Tahun 1995 Tentang Pemasyarakatan, yang memberikan peluang akan haknya bagi setiap narapidana untuk mendapatkan remisi tanpa kecuali para koruptor, sehingga tidak terjadi tumpang tindih kebijakan. 


\section{DAFTAR PUSTAKA}

\section{A. Buku.}

A. Mukhtie Fadjar, Tipe Negara Hukum, Bayumedia Publishing, Malang, 2005.

Abdul Latif, Fungsi Mahkamah Konstitusi Dalam Upaya Mewujudkan Negara Hukum Demokrasi, Total Media, Yogyakarta, 2007.

Abu Fida' Abdur Rafi',, Terapi Penyakit Korupsi dengan Tazkiyatun Nafs (Penyucian Jiwa), Republika, Jakarta, 2006.

Andi Hamzah dan Siti Rahayu, Suatu Tinjauan Ringkas Sistem Pemidanaan Di Indonesia, Akademiko Pesindo, Jakarta, 1983.

Dwidja Priyatno, Sistem Pelaksanaan Pidana Penjara Di Indonesia, Cet. 2, PT. Refika Aditama, Bandung, 2009.

Barda Nawawi Arief dan Muladi, Pidana dan Pemidanaan, F.H, Unsoed, Purwokerto, 1983.

Barda Nawawi Arief, Kebijakan Legislatif Dalam Penanggulangan Kejahatan dengan Pidana Penjara, Cetakan Keempat, Genta Publishing, Yogyakarta, 2010.

Brian Z. Tamahana, On the Rule of Law, History, Politics, Theory, Cambridge University Press, 2004.

CI. Harsono, Sistem Baru Pembinaan Narapidana, Djambatan, Jakarta, 1995.

H.W.R. Wade, Administrative Law, Third Edition (Oxford: Clarendon Press, 1971).

Karl O. Christiansen, Some Consideration on the Possibility of a Rational Criminal Policy. UNAFEI No. 7, 1974.

Liona Nanang Supriatna, The Implementation of Internasional Hukum Rights Law in The Internasional Legal System, Johannes Herrmann Verlag, Gieben, 2008.

Muhammad Tahir Azhari, Negara Hukum Studi Tentang Prinsip-prinsipnya dilihat dari Segi Hukum Islam, Implementasinya pada Periode Negara Madinah dan Masa Kini, Cet. II, Prenada Media, Jakarta, 2003.

Muladi, Lembaga Pidana Bersyarat, Alumni, Bandung, 1992. 
Munir Fuady, Teori Negara Hukum Modern (Rechtstaat), Refika Aditama, Bandung, Cetakan Kedua, 2009.

N.E. Algra dan H.C.J.G. Jansen, Rechtsingang Een Orientasi in Het Recht, H.D. Tjeenk Willink bv, Groningen, 1974.

P.J.P. Tak, Rechtsvorming in Nederland, Samsom H.D. Tjeenk Willink, 1991.

Padmo Wahyono, Pembangunan Hukum DI Indonesia, Ind-Hill Co, Jakarta, 1989.

Petrus Irwan Panjaitan Dan Pandapotan Simorangkir, Lembaga Pemasyarakatan Dalam Perspektif Sistem Peradilan Pidana, Pustaka Sinar Harapan, Jakarta, 1995.

Topo Santoso, Membumikan Hukum Pidana Islam Penegakan Syariat Dalam Wacana Dan Agenda, Gema Insani, Jakarta, 2003.

B. Peraturan Perundang-Undangan.

Undang-Undang Dasar Negara Republik Indonesia Tahun 1945.

Undang-Undang No. 23 tahun 2006 Tentang Administrasi Kependudukan.

Undang-Undang No.12 Tahun 1995 Tentang Pemasyarakatan.

Peraturan Pemerintah No. 32 Tahun 1999 Tentang Syarat dan Tata cara Pelaksanaan Hak Warga Binaan Pemasyarakatan.

Peraturan Pemerintah Nomor 99 Tahun 2012 Tentang Perubahan Kedua Atas Peraturan Pemerintah Nomor 32 Tahun 1999 Tentang Syarat Dan Tata Cara Pelaksanaan Hak Warga Binaan Pemasyarakatan.

C. Internet, Kamus, Majalah, Jurnal, koran dll.

Al-Qur'an dan Terjemahnya, Yayasan Penyelenggara Penterjemah/Pentafsir AlQur'an, Jakarta, 1971.

A. Hamid S. Attamimi, Teori Perundang-Undangan Indonesia, Makalah pada Pidato Upacara Pengukuhan Jabatan Guru Besar Tetap di Fakultas Hukum UI Jakarta, 25 April 1992.

Ajarotni, Suradji, dan Theodrik Simorangkir (Editor), Penelitian Hukum tentang Aspek Hukum Pemberantasan Korupsi di Indonesia, Badan Pembinaan Hukum Nasional, Departemen Hukum dan Hak Asasi Manusia RI, Jakarta, 2008. 
Anton baker, dalam St. Harum Pudjiarto, RS, Hak Asasi Manusia Kajian Filosofis dan Implementasinya Dalam Hukum Pidana di Indonesia, Universitas Atmajaya, Yogyakarta, 1999.

Bambang Poernomo, Perspektif Hukum Pelaksanaan Pidana Berdasarkan Pengayoman, Makalah Seminar, Pascasarjana UGM, Yogyakarta, 22 September 1990.

Jimly Asshiddiqie, Cita Negara Hukum Indonesia, Pidato Orasi Ilmiah Pada Wisuda Sarjana Hukum Fakultas Hukum Sriwijaya Palembang Tanggal 23 Maret 2004, dimuat dalam Jurnal Hukum Simbur Cahaya No. 25 Tahun IX Mei 2005.

M. Abdul Kholiq, "Eksistensi dalam Peradilan Korupsi di Indonesia", Jurnal Hukum, No. 26 Vol 11 Mei 2004.

Sigit Setyadi, Kebijakan Pemberian Remisi Kepada Narapidana Di Yogyakarta, Tesis, Program Magister Ilmu Hukum, Universitas Diponegoro, Semarang, 2005.

Soetanto Soepiadhy, Gerakan Indonesia Patut, Mingguan Opini Kolom Suara Sejati, Edisi 10 Tahun I tanggal 18-16 September, Jakarta, 2005.

Vide Al-Qur'an, Yayasan Penyelenggara Penterjemah/Pentafsir Al-Qur'an, Jakarta, 1971. 